\title{
GROUNDS FOR DISPENSING WITH PUBLIC TENDER PROCEDURES IN GOVERNMENT CONTRACTING*
}

P Bolton ${ }^{* *}$

\section{Introduction}

Procurement is generally described as the function of purchasing goods and services from an outside body. ${ }^{1}$ In South Africa, public sector procurement or government procurement is estimated to amount to approximately $14 \%$ of gross domestic product (GDP). ${ }^{2}$ In the United Kingdom, it is estimated that the total value of public procurement (excluding the procurement of public corporations) was $£ 117$ billion in $2002 / 3^{3}$ and in the United States, the monetary value of public sector contracts given to the private sector is estimated to be about $15 \%$ of GDP. ${ }^{4}$ Government procurement is, therefore, of huge economic significance. Government procurement is, moreover, of major importance for the economic development of a country, particularly in respect of projects involving infrastructure and telecommunication. A government can use its procurement power to promote social and policy objectives by, for example, promoting the development of previously disadvantaged groups. The size and volume of government procurement does, however, give rise to considerable

* This article is based on sections of the author's unpublished doctoral thesis, The Legal Regulation of Government Procurement in South Africa (University of the Western Cape, 2005).

** Senior Lecturer in Law, University of the Western Cape. The financial support of DAAD (Deutscher Akademischer Austausch Dienst / German Academic Exchange Service) and the Research Development Office of the University of the Western Cape in 2004/2005 is gratefully acknowledged. I am also indebted to Julia Sloth-Nielsen and Tobias Van Reenen for their comments on an earlier draft of this paper.

1 Arrowsmith et al. Regulating Public Procurement 1. Collins English Dictionary 1294 similarly defines procurement as "the act of buying". In the South African context, as is argued in greater detail elsewhere (Bolton Government Procurement ch 3, par 8.3.2.3), the word 'procurement', as contained in the heading of s 217 of the Constitution of the Republic of South Africa 1996 (the Constitution) should be given a wide interpretation. Procurement, in the South African context, should be understood as referring to instances when the government acquires goods or services and when it sells or lets assets.

2 Mkhize "No title".

3 Arrowsmith Public and Utilities Procurement par 1.1 (n omitted).

4 Amos 2005 http://www.egovmonitor.com/ 12 May. 
potential for corruption. Both contractors and public officials may resort to corrupt practices, and this may be for personal or political reasons. Whatever the underlying reasons, corruption undermines the attainment of value for money in government contracting, the fair treatment of contractors and the use of procurement as a policy tool.

The South African Constitution provides that when organs of state procure goods or services, they must comply with five principles: fairness, equity, transparency, competitiveness and cost-effectiveness. ${ }^{5}$ In short, ${ }^{6}$ this means that organs of state should make use of competition when procuring goods or services. They should 'shop around' and attract the maximum number of contractors who will participate in such competition. ${ }^{7}$ The aim should be to ensure the attainment of value for money - public money should be spent in an effective and efficient manner. ${ }^{8}$ Those who participate in competitions should also be treated fairly and without bias. ${ }^{9}$ Thus, all contracting parties should have equal access to competition; some contractors should not be afforded more time for the preparation and submission of quotes or tenders than others; and the same information should be made available to all contracting parties. Government procurement procedures should further be transparent, ${ }^{10}$ meaning 'public' or 'open'. ${ }^{11}$ Thus, when organs of state procure goods or services, this should not be done behind closed doors. Procurement information should be generally available; there should be publication of general procurement rules and practices; government contracts should be advertised; contractors should be able to access information on government contract awards; and organs of

5 S 217(1).

$6 \quad$ For detailed discussion, see Bolton Government Procurement ch 3, par 4.

7 On 'competitiveness' and competition, see Collins English Dictionary 345; OED http://www.oed.com/ 28 Oct; Burton Legal Thesaurus 97; Goyder EC Competition Law 8.

8 On 'cost-effectiveness', see Collins English Dictionary 380 and 524; s 33(3)(c), 195(1)(b) and 215(1) of the Constitution. The COED http://www.askoxford.com 25 Jan also defines the word 'cost-effective' as "working productively with minimum wasted effort or expense".

9 On 'fairness', see Collins English Dictionary 586; Claassen Legal Words and Phrases 228; Burton Legal Thesaurus 228; OED http://www.oed.com/ 28 Oct; COED http://www.askoxford.com 25 Jan.

10 S 217(1) of the Constitution.

11 Burton Legal Thesaurus 515. 
state should disclose the criteria that will be applied in selecting a winning contractor. $^{12}$

Depending on the nature and value of a particular contract, the use of a public call for tenders can generally be regarded as the best way to ensure compliance with the principles in section 217(1) of the Constitution, that is, fairness, equity, transparency, competitiveness and cost-effectiveness. ${ }^{13}$ By nature, a public call for tenders is open; it assists in the prevention of fraud or favouritism; and ensures that the maximum number of contractors is approached to participate in government procurement procedures, thus affording an equal opportunity to all prospective contractors to contract with the government. An organ of state is also in a position to compare prices and quality and can choose to contract with whoever offers the best deal. Most legislation accordingly proceeds on the basis that procurement takes place by way of tendering. ${ }^{14}$ As a general rule, legislation prescribes that contracts with a high value (above R200 000) are subject to public tender procedures.

There may, however, be instances when the circumstances of a particular case make the use of a public call for tenders inappropriate, regardless of the high value of the contract. Provision is, therefore, made in legislation for exceptions to the prescribed use of tendering. Since tendering is generally the best method to employ to ensure compliance with the principles in section 217(1) of the Constitution, it is important for there to be sufficient guidance on the non-use of tender procedures. The aim of this article is to analyse the legislation providing for exceptions to the use of tendering and to make recommendations on how

12 Evenett and Hoekman Transparency 272; Arrowsmith 1998 ICLQ.

13 A public call for tenders is also generally referred to as 'tendering', 'competitive tendering', 'bidding', 'competitive bidding', 'sealed bidding', 'open tendering', 'a call for competition', 'public advertisement' or 'a call for tenders'. For the purposes of this article, reference will primarily be made to the terms 'tendering' and 'competitive bidding'. In practice, however, the different terms are often used interchangeably.

14 See, e.g., the Preferential Procurement Policy Framework Act 5 of 2000 (Procurement Act) and the Regulations thereto - Preferential Procurement Regulations GG No 22549 of 10 August 2001. These (2001) Regulations are currently (30 April 2006) in the process of being redrafted - Preferential Procurement Policy Framework Act, 2000 (Act 5 of 2000): Draft Preferential Procurement Regulations GG No 26863 of 4 October 2004. 
some of the legislative provisions should be interpreted in order to align them with the principles in section 217(1) of the Constitution.

First, the different ways in which legislation makes provision for the non-use of tendering will be enquired into. Guidance will then be provided on how certain legislative provisions should be interpreted to ensure compliance with section 217(1) of the Constitution. In doing so, reference will be made to international instruments dealing with government procurement and, specifically, the nonuse of tender procedures. ${ }^{15}$ Readers are warned not to expect extensive reference to applicable case law. The reason for this is that in those instances where organs of state fail to make use of public tender procedures, affected parties are seldom aware of this. Also, even where decisions not to use tender procedures are known to affected parties, they are generally unlikely to experience such an instant or direct sense of unfairness as with decisions made in the course of public tender procedures. Case law dealing with the nonuse of public tender procedures is accordingly scarce, especially in the South African context. As far as possible, however, use will be made of practical examples.

\section{Exceptions as provided for in legislation}

\subsection{Overview of legislation}

15 E.g., United States Federal Acquisition Regulations (US FAR); the UNCITRAL http://www.uncitral.org 28 Oct; the European Community's new Public Procurement Directives (Directive 2004/18/EC on the coordination of procedures for the award of public works contracts, public supply contracts and public service contracts - [2004] Official Journal of the European Union L 134/114 (EC Public Sector Directive); and Directive 2004/17/EC on coordinating the procurement procedures of entities operating in the water, energy, transport and postal services sectors - [2004] Official Journal of the European Union L 134/1 (EC Public Utilities Directive)); the WTO GPA http://www.wto.org 28 Oct; and the new Polish Public Procurement Act. At times, reference will also be made to the Ministry of Finance and Public Works: Green Paper on Public Sector Procurement Reform in South Africa, GG No 17928 of 14 April 1997; and the Supply Chain Management Policy - see City of Cape Town http://www.capetown.gov.za/ 4 Apr. 
At national and provincial government level, the Public Finance Management Act $(\mathrm{PFMA})^{16}$ regulates financial management in the national and provincial governments and provides, inter alia, that the National Treasury may make Regulations or issue instructions, applicable to all institutions to which the PFMA applies, concerning -

...the determination of a framework for an appropriate procurement and provisioning system which is fair, equitable, transparent, competitive and cost-effective. ${ }^{17}$

The Regulations in terms of the PFMA (PFMA Regulations) have been promulgated $^{18}$ and the Supply Chain Management Regulations (PFMA SCM Regulations), ${ }^{19}$ in particular, make provision for the implementation of supply chain management systems by organs of state (falling within the Regulations) for the acquisition of goods and services and the disposal and letting of government assets. ${ }^{20}$ The Regulations provide that supply chain management systems implemented by organs of state must comply with the principles of fairness, equity, transparency, competitiveness and cost-effectiveness. ${ }^{21}$ The procurement of goods and services must further take place either by way of quotations or through a bidding process, and must be in accordance with the threshold values as determined by the National Treasury. ${ }^{22}$

The National Treasury has issued guidelines and instructions or practice notes on various issues relating to procurement, the aim being to ensure uniform minimum norms and standards within government. Of particular relevance is Practice Note Number SCM 2 of $2005^{23}$ which makes provision for four types of procurement: petty cash purchases, verbal or written quotations, written price

16 Act 1 of 1999, as amended by Act 29 of 1999.

$17 \mathrm{~S} 76(4)(c)$.

18 National Treasury: Regulations for Departments, Trading Entities, Constitutional Institutions and Public Entities: Issued in terms of the Public Finance Management Act 1999, GG No 27388 of 15 March 2005.

19 Can be found in reg $16 \mathrm{~A}$ of the PFMA Regulations.

20 Reg 16A3.1.

21 Reg 16A3.2.

22 Reg 16A6.1.

23 National Treasury 2005 http://www.treasury.gov.za/ 14 Apr. 
quotations and competitive bidding. Petty cash purchases are prescribed for contracts up to R2 000, written or verbal quotations are prescribed for contracts over R2 000 but under R10 000, written price quotations should be obtained for contracts over R10 000 but under R200 000, and competitive bidding should be used for contracts over R200 000. The rule, therefore, is that the procurement of goods or services above R200 000 is subject to formal procedures, that is, public tender procedures.

Very similar provisions are contained in the legislation applicable to local government. The Local Government: Municipal Finance Management Act $(\mathrm{MFMA})^{24}$ aims, inter alia -

...[t]o secure sound and sustainable management of the financial affairs of municipalities and other institutions in the local sphere of government. $^{25}$

The MFMA provides that organs of state (falling within the ambit of the Act) must have and implement a supply chain management policy which is 'fair, equitable, transparent, competitive and cost-effective'. ${ }^{26}$ A supply chain management policy must also comply with a prescribed regulatory framework ${ }^{27}$ which complies with the principles of fairness, equity, transparency, competitiveness and cost-effectiveness. ${ }^{28}$

The Supply Chain Management Regulations to the MFMA (MFMA SCM Regulations) have been promulgated ${ }^{29}$ and make provision for a range of procurement processes. ${ }^{30}$ Petty cash purchases are prescribed for contracts up to R2 000, written or verbal quotations are prescribed for contracts over R2 000 but below R10 000, formal written price quotations should be obtained for

24 Local Government: Municipal Finance Management Act 56 of 2003.

25 Preamble to the MFMA.

26 S 111 read with s 112(1).

27 See the whole of $s$ 112(1).

28 S 112(2).

29 Local Government: Municipal Finance Management Act 2003: Municipal Supply Chain Management Regulations GG No 27636 of 30 May 2005.

30 MFMA SCM reg 12. 
contracts over R10 000 but below R200 000, and competitive bidding should be used for contracts over R200 000 and for contracts with a duration period exceeding one year. ${ }^{31}$ Provision is also made for a two-stage bidding process ${ }^{32}$ for -

(a) large complex projects; (b) projects where it may be undesirable to prepare complete detailed technical specifications; or (c) long term projects with a duration period exceeding three years. ${ }^{33}$

Of particular relevance, therefore, is that a public tender process is prescribed for contracts exceeding one year and for procurements above R200 000. ${ }^{34}$ Contracts for the provision of banking services must also be procured by way of tender procedures. ${ }^{35}$

At all three levels of government, the requirement for the use of public tender procedures is not without exception. In the ensuing paragraph, attention will be given to the different ways in which legislation (at all three levels of government) makes provision for exceptions to the prescribed use of tendering. Thereafter, an analysis will be offered of such legislation. It is important to note that attention will not be given to the use of petty cash purchases, written or verbal quotations, formal written price quotations, or two-stage bidding. The

31 Reg 12(2)(a) provides that "[a] supply chain management policy may allow the accounting officer to lower, but not to increase, the different threshold values specified in subregulation (1)". Written or verbal quotations may, e.g., be obtained for contracts under R2 000 , formal written price quotations may be obtained for contracts under R10 000, or competitive bidding may be used for contracts under R200 000 (reg 12(2)(b)). A supply chain management policy must also state that "goods or services may not deliberately be split into parts or items of a lesser value merely to avoid complying with the requirements of the policy" (reg 12(3)(a)).

32 Also referred to as 'restricted invitation' or 'selective tendering'.

33 Reg 25(1). In terms of a two-stage bidding process, a public call for 'proposals to tender', 'expressions of interest' or 'requests to tender' go out and contractors are invited to submit detailed technical and cost proposals by a specified date. The number of proposals received is then reduced. Only those contractors who are identified as most likely to provide responsive and cost-effective tenders, and are most likely to perform in terms of their contractual obligations, are then invited to tender. The actual process of tendering is thus limited to a 'reasonable' number of contractors so that an organ of state's resources for tender evaluation is not unnecessarily strained by the need to review tenders submitted by unqualified contractors.

34 MFMA SCM reg 12(1)(d).

35 MFMA SCM reg 30(1). 
primary focus will be on the prescribed use of public tender procedures and the exceptions provided for in legislation for the non-use of such procedures.

\subsection{Prescribed exceptions to public tendering}

\subsubsection{When 'impractical', in case of 'emergencies' and/or 'sole providers' ${ }^{36}$}

At national and provincial government level, Practice Note Number SCM 2 of 2005 provides for the non-use of tender procedures if it is "impractical to invite competitive bids", for example, in the case of 'emergencies' or a 'sole supplier'. ${ }^{37}$ In such instances, procurement may take place by other means, such as price quotations or negotiations, provided that a record is kept of the reasons for deviating from an invitation for competitive bids and such reasons are approved by the relevant authority. ${ }^{38}$ The PFMA SCM Regulations contain a similar provision. ${ }^{39}$

At local government level, organs of state may also dispense with official procurement processes, and these include public tender procedures, and procure goods or services "through any convenient process, which may include direct negotiations". ${ }^{40}$ This may, however, only be done in case of 'emergencies'; if the goods or services are only available from a 'single provider'; or in 'any other exceptional case' where it is 'impractical or impossible' to follow official procurement procedures. ${ }^{41}$ The reasons for any deviations must be recorded and reported to the next meeting of the council, or board of

36 It is useful, at this stage, to discuss these three grounds under one heading. When guidelines are, however, provided for the interpretation of the different grounds (see par 4 below), the grounds will be examined separately.

37 Par 4.4.

38 Ibid.

39 Reg 16A6.4.

40 MFMA SCM reg 36(1)(a).

41 MFMA SCM reg 36(1)(a)(i), 36(1)(a)(ii) and 36(1)(a)(v). Organs of state may also dispense with official procurement processes (including tender procedures) for "the acquisition of special works of art or historical objects where specifications are difficult to compile"; and the acquisition of animals for zoos (MFMA SCM reg 36(1)(a)(iii) and 36(1)(a)(iv)). 
directors in the case of a municipal entity, and a note to this effect must be included in the annual financial statements. ${ }^{42}$

\subsubsection{Municipal service delivery by another organ of state}

In the municipal service delivery context, there is no need to make use of competition, and this includes tender procedures, if an organ of state contracts with another organ of state (as opposed to a private party) for the delivery of a municipal service. ${ }^{43}$ There are many rules and procedures in place for the contracting out of municipal services. ${ }^{44}$ The five principles in section $217(1)$ of the Constitution are, for example, repeated in section 83(1)(a) of the Municipal Systems Act, but they only find application when a municipality decides to make use of a private party for the delivery of a municipal service and not when use is made of another organ of state. ${ }^{45}$ The position appears to be the same insofar as the disposal of capital assets is concerned. ${ }^{46}$ The principles of

42 MFMA SCM reg 36(2). This reg (36(2)) does not apply to the procurement of, e.g., water and electricity (MFMA SCM reg 36(3)). See also s 10G(5)(c) of the Local Government Transition Act 209 of 1993 (Local Government Transition Act) which provides that a municipality may dispense with the calling of tenders "within such limits as may be prescribed by a national law".

43 S 76 of the Local Government: Municipal Systems Act 32 of 2000, as amended by Act 44 of 2003 (Municipal Systems Act) expressly provides that a municipality can either deliver municipal services itself (in-house) or use can be made of an external provider. A 'municipal service', in turn, is defined as "a service that a municipality in terms of its powers and functions provides or may provide to or for the benefit of the local community irrespective of whether (a) such a service is provided, or to be provided, by the municipality through an internal mechanism contemplated in section 76 or by engaging an external mechanism contemplated in section 76; and (b) fees, charges or tariffs are levied in respect of such a service or not" (s 35 of the Local Government Laws Amendment Act 51 of 2002 which amends $\mathrm{s} 1$ of the Municipal Systems Act).

44 See ch 8 of the Municipal Systems Act.

$45 \mathrm{~S} 80(1)$ of the Municipal Systems Act provides that "[i]f a municipality decides to provide a [municipal] service through a service delivery agreement in terms of section $76(b)$ with (a) a municipal entity, another municipality or a national or provincial organ of state, it may negotiate and enter into such an agreement with the relevant municipal entity, municipality or organ of state without applying Part 3 of this Chapter; or (b) any institution or entity or any person, juristic or natural, not mentioned in paragraph (a), it must apply Part 3 of this Chapter before entering into such an agreement with any such institution, entity or person" (emphasis added). Part 3 of the Act, inter alia, repeats the principles laid down in s 217(1) of the Constitution and provides (in s 83(1)) that "[i]f a municipality decides to provide a municipal service through a service delivery agreement with a person referred to in section 80(1)(b), it must select the service provider through selection processes which (a) are competitive, fair, transparent, equitable and cost-effective". 
fairness, equity, transparency and competitiveness (not cost-effectiveness) are repeated in section 14(5) of the MFMA. Section 14(6), however, provides that 'this section', in other words, the whole of section $14-$

...does not apply to the transfer of a capital asset to another municipality or to a municipal entity or to a national or provincial organ of state in circumstances and in respect of categories of assets approved by the National Treasury, provided that such transfers are in accordance with a prescribed framework. ${ }^{47}$

It would appear that the reason for the non-application of the principles in the above instances, and thus also the non-use of tender procedures, is that all organs of state are entities exercising powers on behalf of the state. No organ of state is separate from the state - the state, through its organs, at all times functions as a unit. Thus, when a municipality, for example, contracts with another organ of state for the delivery of a municipal service, the service will still be provided by the state. There is, accordingly, no need for the principles in section $217(1)$ of the Constitution to find application. There is, therefore, no need for tender procedures. It is submitted, however, that even though the principles in section 217(1) do not find application where a municipality contracts with another organ of state for the delivery of a municipal service, for example, municipalities must, as a general rule, always comply with the principle of transparency. ${ }^{48}$ The public, as taxpayers, have a right to government contracting procedures that are open and transparent irrespective of whether a municipality contracts with a private party or another organ of state. This is in line with one of the core aims of the Constitution, that is, to "lay the foundations for a democratic and open society". ${ }^{49}$

Where a municipality is not specifically contracting with another organ of state for the delivery of a municipal service, and/or is contracting for goods or

47 Emphasis added.

48 Penfold and Reyburn Public Procurement 25-11 (n 1) note that an exception to compliance with the principle of transparency may be "where compelling reasons, such as national security, militate against disclosing any issues relating to the proposed contract". The writers, however, caution that "[t]his would only arise in highly exceptional circumstances". See also par 4.1 .4 below.

49 See the Preamble to the Constitution (emphasis added). 
services in general, it would appear that the municipality will be bound by section 217, and thus the use of tender procedures, irrespective of whether a contract is ultimately concluded with a private party or another organ of state. ${ }^{50}$ The same applies to instances where an organ of state in the national or provincial government sphere contracts for goods or services. It is submitted that this will particularly be the case where commercial entities performing public powers or functions participate in the procurement process. Such entities, as organs of state, will have a right to procurement procedures that are fair, equitable, transparent, competitive and cost-effective. ${ }^{51}$

\subsubsection{Participation in a transversal term contract}

The National Treasury facilitates the arrangement of contracts, referred to as transversal term contracts, for the procurement of goods and services required by more than one government department provided that the arrangement of such contracts is cost-effective and in the national interest. ${ }^{52}$ The PFMA SCM Regulations (applicable to national and provincial government) accordingly provide that if an organ of state participates in a transversal term contract facilitated by the relevant treasury, it may not call for tenders for the same or similar product or service during the existence of the transversal term contract. $^{53}$

\subsubsection{Contracts arranged by other organs of state}

The PFMA SCM Regulations (applicable to national and provincial government) provide that an organ of state may partake in any contract arranged by means of a tender process by any other organ of state, subject to the written approval

50 See, however, cl 261.4.4 of the Supply Chain Management Policy - City of Cape Town http://www.capetown.gov.za/ 4 Apr, which makes provision for the non-use of a tendering process in relation to "any contract with an organ of state, a local authority or a public utility corporation or company".

51 S 217(1) of the Constitution.

52 National Treasury http://www.treasury.go.za/ 14 Apr.

53 Reg 16A6.5. 
of such organ of state and the relevant contractors. ${ }^{54}$ There is thus no need for an organ of state to conduct its own tender procedures. If the needs of an organ of state $(X)$ are similar to the needs of another organ of state $(Y)$, and $Y$ has already arranged to meet its needs by means of tender procedures, $X$ can simply arrange with $Y$ to make use of the same contractor that $Y$ selected to satisfy its needs. The contractor concerned should, however, as noted, also agree to the arrangement in writing.

Organs of state at local government level may similarly procure goods or services under a contract secured by another organ of state by means of tender procedures. ${ }^{55}$ There would, therefore, be no need to make use of tender procedures under these circumstances. The conditions, however, are the following: (a) the organ of state that initially secured the contract must have done so by way of a tender process; (b) the organ of state who wants to participate in the contract should have no reason to believe that the contract was not validly procured; (c) the organ of state who wants to participate in the contract should obtain 'demonstrable discounts or benefits' as a consequence; and (d) the other organ of state and the provider must give written approval to the procurement in question. ${ }^{56}$

\section{Analysis of legislation}

The legislative provisions applicable to national, provincial and local government do not provide sufficient guidance on the non-use of tender procedures. This is particularly the case with regard to instances when it is 'impractical' to call for tenders, and in the case of 'emergencies' and the use of 'single source procurement'. The PFMA SCM Regulations (applicable to

54 Reg 16A6.6. See also City of Cape Town http://www.capetown.gov.za/ 4 Apr, Supply Chain Management Policy cl 261.4.5.

55 MFMA SCM reg 32(1).

56 MFMA SCM reg 32(1)(a)-(d). An organ of state or municipality need not meet the latter two conditions if the goods or services are procured "through a contract secured by its parent municipality" or the goods or services are procured "through a contract secured by a municipal entity of which it [the municipality] is the parent municipality" (MFMA SCM reg 32(2)). 
national and provincial government), for example, provide for procurement 'by other means' where it is 'impractical' to invite tenders but no guidance is given as to when, and in what instances, the calling of tenders would be 'impractical'. ${ }^{57}$ There is also no guidance in the Regulations on what is meant by 'other means' of procurement. Provision is also made for reasons to be submitted to the relevant authority for deviating from inviting tenders, but no suggestions are made as to what kinds of reasons would justify the deviation. ${ }^{58}$ There is, therefore, a wide discretion in this regard.

Practice Note Number SCM 2 of 2005 sheds some light on when the calling of tenders may be 'impractical' and when use may be made of 'other means' of procurement. Specific reference is made to "urgent or emergency cases or in case of a sole supplier" 59 and procurement by other means, "such as price quotations or negotiations". 60 Still, however, no guidance is given on what may constitute an 'emergency' or situations that may warrant the use of 'single source procurement'.

At local government level, the MFMA SCM Regulations similarly refer to 'emergency' situations and where goods are available from 'a single provider' as justification for the non-use of tender procedures. ${ }^{61}$ Reference is also made to procurement "through any convenient process, which may include direct negotiations". ${ }^{62}$ As is the case at national and provincial government level, however, no guidance is given on what may constitute an 'emergency' or situations that may warrant the use of 'single source procurement'.

57 Reg 16A6.4.

58 Ibid.

59 Par 4.4. See also a 22 of UNCITRAL http://www.uncitral.org 28 Oct which provides that a procuring entity may engage in 'single-source procurement' in a number of situations, including where the goods, construction or services are 'urgently required'.

60 Par 4.4.

61 MFMA SCM reg 36(1)(a)(i) and 36(1)(a)(ii). See also s 10G(5)(c) of the Local Government Transition Act which provides that "[a] municipality may dispense with the calling of tenders in the case of an emergency".

62 MFMA SCM reg 36(1)(a). 
For contracts with a high value (above R200 000), tendering is the best way to ensure compliance with the principles in section 217(1) of the Constitution, that is, fairness, equity, transparency, competitiveness and cost-effectiveness. ${ }^{63}$ Proper guidance on exceptions to the use of tender procedures is, therefore, crucial. It will, to a large extent, ensure uniformity insofar as the submission of reasons is concerned, and ensure transparency in government procurement procedures which will, in turn, assist in the combating of corruption. The aim in the ensuing paragraph is to make suggestions for the interpretation of the relevant legislative provisions providing for exceptions to the use of tendering in order to align them with the principles in section $217(1)$ of the Constitution.

\section{$4 \quad$ Suggested guidelines for interpreting legislative provisions}

In this paragraph, guidance will be provided on (1) instances when the use of tendering may be 'impractical'; 64 (2) circumstances that may amount to 'emergencies'; 65 and (3) circumstances that may warrant the use of 'single source procurement'. ${ }^{66}$

\subsection{When tendering may be 'impractical'}

\subsubsection{Unknown specifications}

The use of tendering may be 'impractical' where, for example, repairs need to be done and it is not possible for an organ of state to ascertain the nature or

63 See also par 1 supra.

64 As provided for in reg 16A6.4 of the PFMA SCM Regulations, par 4.4 in Practice Note Number SCM 2 of 2005, and MFMA SCM reg 36(1)(a)(v).

65 As provided for in par 4.4 in Practice Note Number SCM 2 of 2005, reg 16A6.4 of the PFMA SCM Regulations, and MFMA SCM reg 36(1)(a)(i).

66 As provided for in par 4.4 in Practice Note Number SCM 2 of 2005, reg 16A6.4 of the PFMA SCM Regulations, and MFMA SCM reg 36(1)(a)(ii). 
extent of the work required. ${ }^{67}$ Characteristically, a call for tenders requires an organ of state to specify its needs to potential contractors. A call for tenders must thus contain detailed specifications to enable interested parties to prepare and submit responsive tenders. Where specifications are not known to an organ of state, a public tender process is clearly impractical. ${ }^{68}$ The MFMA SCM Regulations (applicable to local government) give recognition to this and stipulate one instance when an organ of state may deviate from official procurement processes, that is, when acquiring -

...special works of art or historical objects where specifications are difficult to compile. ${ }^{69}$

\subsubsection{Receipt of no, 'inappropriate' or 'unacceptable' tenders}

A tender procedure may be 'impractical' where there has been a call for tenders and no tenders, or 'inappropriate' or 'unacceptable' tenders were received. Tenders may be regarded as 'inappropriate' or 'unacceptable' if the prices offered were too high; unsuitable technical solutions were offered; none of the tenders received complied with the specifications and conditions of the tender call; ${ }^{70}$ and/or there has been collusion in the submission of tenders. ${ }^{71}$ An organ of state may then make use of some other procurement method, for example, verbal or written quotations, or written price quotations since calling for tenders a second time may be too costly. It may also be able to do away with competition entirely and enter into negotiations with a particular supplier.

67 See also cl 261.4.7 of the Supply Chain Management Policy - City of Cape Town http://www.capetown.gov.za/ 4 Apr; and the Green Paper on Public Sector Procurement Reform, cl 4.15.

68 A useful method of procurement to use in such a case may be to invite contractors to submit 'on the site quotations'. Doing so will ensure that procurement is still competitive.

69 MFMA SCM reg 36(1)(a)(iii). See also note 41 supra.

70 S 1(i) of the Procurement Act defines an 'acceptable tender' as "any tender which, in all respects, complies with the specifications and conditions of tender as set out in the tender document".

71 See also a XV par 1(a) of the WTO GPA http://www.wto.org 28 Oct; a 62(1)(1) of the new Polish Public Procurement Act; a 31(1)(a) of the EC Public Sector Directive; and a 40(3)(a) of the EC Public Utilities Directive. 
However, this form of procurement, that is, single source procurement, is open to abuse and is dealt with in greater detail below. ${ }^{72}$

\subsubsection{Best value}

The use of tendering may be 'impractical' for reasons exclusively related to best value. An organ of state may, for example, protect its future procurement interests and award a contract to a particular contractor to enable it to stay in the market and so avoid a monopoly situation in the specific goods or services in future. ${ }^{73}$ An organ of state may also be confronted with 'bargain purchases' where it is possible to obtain goods by taking advantage of a particularly beneficial opportunity available for a very short period of time at a price significantly lower than ordinary market prices. ${ }^{74}$ Goods may also be available -

...on particularly advantageous terms from either a supplier which is definitely winding up its business activities, or the receivers or liquidators of a bankruptcy, an arrangement with creditors, or a similar procedure under national laws or regulations. ${ }^{75}$

\subsubsection{National security}

Reasons of national security could justify the non-use of tender procedures. ${ }^{76}$ This is likely to be the case where a call for tenders would require the circulation of specifications for military equipment. ${ }^{77}$ This, of course, does not mean that a contract for military equipment may necessarily be awarded

72 Par 4.3.

73 Arrowsmith Procurement and Judicial Review 64.

74 A XV par 1(i) of the WTO GPA http://www.wto.org 28 Oct; a 31(2)(d) of the EC Public Sector Directive; and a 40(3)(j) of the EC Public Utilities Directive. See also Trepte Public Procurement in the EC 131.

75 A $31(2)(d)$ of the EC Public Sector Directive; and a 40(3)(j) of the EC Public Utilities Directive.

76 See a 19(1)(c) of UNCITRAL http://www.uncitral.org 28 Oct; US FAR 6.302-6. Contracts that involve national defence or national security may also justify the non-use of competition altogether or the use of single source procurement. On the use of single source procurement, see par 4.3 below.

77 Arrowsmith Procurement and Judicial Review 64. 
without resorting to some form of competitive procedure. ${ }^{78}$ An organ of state may, for example, dispense with a call for tenders, for fear of making its military requirements known to a potential enemy, but nevertheless "conduct a competition amongst invited and trusted [contractors]". ${ }^{79}$ At national and provincial government level, Practice Note Number SCM 2 of 2005 makes provision for procurement "by other means, such as price quotations or negotiations". ${ }^{80}$ Where procurement takes place "by other means, such as price quotations or negotiations", however, it is (still) important that all contractors who are invited to participate have access to the relevant documentation, requirements and guidelines on an equal basis. This will ensure genuine competition and fairness to all concerned.

\subsubsection{Professional advice or services}

At local government level, the MFMA SCM Regulations stipulate that an organ of state must make use of tendering for the appointment of consultants in the case of contracts above R200 000 or contracts that exceed one year. ${ }^{81}$ It is submitted, however, that the use of public tendering may be 'impractical' where a consultant will be required to "provide professional advice or services". 82 A tender procedure, by nature, requires an organ of state to provide detailed specifications to enable contractors to prepare and submit responsive tenders. The provision of detailed specifications may be very difficult where an organ of state needs professional advice or services - an organ of state may not necessarily know the nature, extent or scope of services to be performed. It is particularly in the area of "research and development, policy formulation,

78 Arrowsmith et al. Regulating Public Procurement 550 point out that "[n]ational security by itself does not necessarily justify single source procurement [i.e., the non-use of competition]. In fact, it may justify competition, albeit on a limited basis to maintain a mobilisation base". According to the writers, much will depend on the nature and importance of the particular goods or services. The question also arises as to the meaning or interpretation of the term 'national security' and whether this interpretation may be challenged by interested and affected parties.

79 Arrowsmith et al. Regulating Public Procurement 582. See also US FAR 6.302-6.

80 Par 4.4.

81 MFMA SCM reg 35(2).

82 See City of Cape Town http://www.capetown.gov.za 28 Oct: Procurement Policy Initiative vol 4 cl 7.1.1; and US FAR 6.302-3. 
human resource development, community-based developments and the like" that it is difficult to define the scope of services prior to the actual commencement of work. ${ }^{83} \mathrm{~A}$ more appropriate procurement method in these instances would be the use of two-stage bidding.

\subsubsection{Other}

The use of tendering may be 'impractical' for the publication of notices and advertisements or where an organ of state is able to acquire goods at a public auction sale. ${ }^{84}$ In the latter case, the reasoning is obvious - the purchase in question will already encompass a competitive procedure. In the former case, on the other hand, a tender process in itself would require the publication of notices and advertisements, that is, a call for tenders.

It has further been held ${ }^{85}$ that where a municipality created a legitimate expectation that a particular party would be afforded preference in buying certain immovable property, the municipality can be prevented from calling for tenders for the sale of such property. ${ }^{86}$ In Ngoasheng v Ekurhuleni Metropolitan Municipality, ${ }^{87}$ the court held that the applicant should have been afforded a right of preference to purchase the immovable property before the decision was made to call for tenders. Having occupied the property in question for an extended period of time (23 years), and in light of the negotiations that took place between the applicant and the municipality (the applicant on numerous occasions offered to purchase the property), a legitimate expectation was

$83 \mathrm{Cl} 4.5$ in the Green Paper on Public Sector Procurement Reform. See also a 19(1)(a) and 19(1)(b) of UNCITRAL http://www.uncitral.org 28 Oct; a 62(1)(3) of the new Polish Public Procurement Act; a 31(2)(a) of the EC Public Sector Directive; and a 40(3)(b) of the EC Public Utilities Directive. See further Turpin Government Procurement and Contracts 4; Bright Public Procurement Handbook 39; Trepte Public Procurement in the EC 128-129. See also par 4.1.1 supra.

84 See, e.g., Supply Chain Management Policy cl 261.4.1 and 261.4.3 - City of Cape Town http://www.capetown.gov.za/ 4 Apr.

85 Ngoasheng v Ekurhuleni Metropolitan Municipality [2004] JOL 12953 (T).

86 In Council of Civil Service Unions v Minister for the Civil Service [1984] 3 All ER 935 (HL) $944 \mathrm{a}$, Lord Fraser said that a "[l]egitimate, or reasonable, expectation may arise either from an express promise given on behalf of a public authority or from the existence of a regular practice which the claimant can reasonably expect to continue".

87 Ngoasheng v Ekurhuleni Metropolitan Municipality [2004] JOL 12953 (T). 
created that the applicant would receive preference in buying the property. The court held that the municipality's actions in calling for tenders for the said property were not transparent or fair to the applicant. The court therefore ordered the municipality to afford the applicant first preference to purchase the property based on a fair price, and that the applicant be given 30 days within which to comply with the offer. If the applicant failed to meet the requirements of the offer, the municipality would be entitled to call for tenders for the sale of the property. ${ }^{88}$

\subsection{Circumstances that may amount to 'emergencies ${ }^{189}$}

Provision is made in legislation at all three levels of government for the non-use of tendering in emergency situations but no guidance is given on situations that may amount to emergencies. The Green Paper on Public Sector Procurement Reform may be used as a guideline when interpreting procurement legislation that deals with emergencies. It provides that emergency situations may include, for example -

...[t]he possibility of human injury or death; [t]he prevalence of human suffering or deprivation of rights; [t]he possibility of damage to property, or suffering and death of livestock and animals; [t]he interruption of essential services, including transportation and communication facilities; [t]he possibility that the security of the State could be compromised; [t] he possibility of serious damage occurring to the natural environment; [and/or] [t]he possibility that failure to take necessary action may result in the State not being able to render an essential community service. ${ }^{90}$

The prevailing situation or imminent danger should, however, -

88 Ibid, par 15.

89 In the United States case of Scaccia $v$ Borough of Old Forge 373 Pa 161, 163; 94 A.2d $563,564 \mathrm{~Pa}$ (1953), the court said that "[i]t is difficult to define an emergency but as a generalization it is a sudden or unexpected event which creates a temporarily dangerous condition usually necessitating immediate or quick action....Ordinary conditions or customarily existing conditions are not emergencies". For certain key features of emergency procurement, see also Schwarts "Katrina's lessons" 2-6. See also generally Katayama 1968-1969 PCLJ; and US FAR 6.302-2.

$90 \mathrm{Cl}$ 4.15. See also City of Cape Town http://www.capetown.gov.za/ 4 Apr: Supply Chain Management Policy cl 265. 
....be of such a scale and nature that it could not readily be alleviated by interim measures, in order to allow time for normal procurement systems to be used. $^{91}$

Available details of the nature and extent of the work and services required should also be inadequate to allow an accelerated or normal procurement system to be used. ${ }^{92}$ During World War I, for example, many contracts in the United States were exempted from the strictness of formal advertising on the basis of 'public exigency'. ${ }^{93}$ More recently, the United States had to respond to the natural disaster commonly known as Hurricane Katrina. The United States' procurement response in this instance is a good illustration of when a government opted to make use of emergency procurement procedures because accelerated or normal procurement procedures were inappropriate under the circumstances. ${ }^{94}$

It should be cautioned that emergency procurement should not be used to evade the use of standard procurement procedures; as a consequence of insufficient stock-levels for items that are used on a daily basis; as a result of working programmes not adequately planned for; or as a result of no or insufficient communication between warehouses and buying offices. ${ }^{95}$ Thus, it is important that the circumstances giving rise to an emergency were not foreseeable by an organ of state, or be the result of negligent conduct on the part of an organ of state. ${ }^{96}$

$91 \mathrm{Cl} 4.15$ in the Green Paper on Public Sector Procurement Reform. See also City of Cape Town http://www.capetown.gov.zal 4 Apr: Supply Chain Management Policy cl 266.

$92 \mathrm{Cl} 4.15$ in the Green Paper on Public Sector Procurement Reform.

93 Katayama 1968-1969 PCLJ 240.

94 For criticism of the United States government's response to Hurricane Katrina, see Schwarts "Katrina's lessons". See also generally, Pool and Welch 2005 http://summitinsight.com/ 25 Jul. See further Madsen et al 2002 http://mayerbrown.com/ 26 Jul on procurement practices being advocated or previously undertaken in emergencies in the United States. The paper identifies potential pitfalls for the United States government if these practices are not properly managed.

95 See City of Cape Town http://www.capetown.gov.za 28 Oct: Procurement Policy Initiative vol $4 \mathrm{cl}$ 7.1.7.

96 See also a 19(2)(a) of UNCITRAL http://www.uncitral.org 28 Oct; a 62(1)(4) of the new Polish Public Procurement Act; a 31(1)(c) of the EC Public Sector Directive; and a $40(3)(d)$ of the EC Public Utilities Directive. 
It is important to note, furthermore, that even in those instances when an emergency situation does warrant the non-use of tender procedures, this does not mean that an organ of state may do away with a competitive procurement process altogether. ${ }^{97}$ Organs of state should still be required, in order to ensure compliance with, in particular, the principles of competitiveness and costeffectives in section 217(1) of the Constitution, to procure the necessary goods or services on the best possible terms. The City of Cape Town Supply Chain Management Policy ${ }^{98}$ makes provision for this and provides that in emergency situations, and where possible, at least three quotes must nevertheless be obtained, failing which the procedures followed must be formalised in a report to the city manager as soon as possible. ${ }^{99}$ Organs of state should, furthermore, where use is made of emergency procurement procedures, carefully consider limiting the value and length of contracts concluded in order to address only the immediate emergency. In this way, ongoing needs and requirements can, as far as possible and where appropriate, be met by way of public tender procedures.

\subsection{The use of 'single source procurement'}

The use of tendering may be inappropriate in instances where there is only one potential provider or authorised provider for the goods or services in question. This is likely to be the case in respect of creative and artistic works; the protection of exclusive rights, such as patents or copyright; or the absence of competition for technical reasons. ${ }^{100}$ In such instances, an organ of state may

97 See cl 4.15 in the Green Paper on Public Sector Procurement Reform.

98 City of Cape Town http://www.capetown.gov.za/ 4 Apr.

$99 \mathrm{Cl}$ 267. See also Anon $2004 \mathrm{~J}$ of Public Procurement. The author makes reference to a number of existing tools in the United States whose flexibility, in the author's opinion, may prove to be advantageous in the case of emergency procurements. Examples include: competition among pre-qualified sources; verbal solicitations; and limited source selections. See also Schwarts "Katrina's lessons"; and US FAR 6.302-2.

100 A XV par 1(b) of the WTO GPA http://www.wto.org 28 Oct; a 67(1) of the new Polish Public Procurement Act; a 31(1)(b) of the EC Public Sector Directive; a 40(3)(c) of the EC Public Utilities Directive; and US FAR 6.302-1. 
resort to 'single source procurement'. ${ }^{101}$ An organ of state may, in other words, enter into negotiations with a specific provider for the procurement of goods or services. ${ }^{102}$ By nature, however, single source procurement lends itself to abuse. In the typical single source procurement, there is no competition or price mechanism. A contractor that knows that it is the only source has no reason to offer competitive pricing. No competitive market exists to provide incentives to the contractor. Single source procurement is possibly also the least transparent of all award procedures. It is in the interests of governments, therefore, to reduce single source awards. ${ }^{103}$

At national and provincial government level, Practice Note Number SCM 2 of 2005 makes provision for the non-use of tendering "in the case of a sole supplier". ${ }^{104}$ At local government level, the MFMA SCM Regulations also provide that organs of state may dispense with official procurement processes and procure goods or services through any convenient process, which may include direct negotiations but only if, inter alia, "such goods or services are produced or available from a single provider only". ${ }^{105}$ No guidance is, however, given on situations that may warrant the use of 'single source procurement'. In the ensuing paragraph, guidance is provided on possible situations that may warrant the use of single source procurement.

\subsubsection{Intellectual property rights}

The use of single source procurement may be warranted where, as noted above, there are intellectual property rights involved such as patents,

101 Also referred to as 'sole source procurement', 'directed contracting', 'negotiated procurement' or 'single tendering' (Arrowsmith et al Regulating Public Procurement). See also generally Turpin Government Procurement and Contracts 144-146.

102 See a 22 of UNCITRAL http://www.uncitral.org 28 Oct which provides that a procuring entity may engage in 'single-source procurement' in a number of situations, including where the goods, construction or services are only available from one supplier or contractor.

103 See also Arrowsmith et al Regulating Public Procurement 537.

104 Par 4.4.

105 MFMA SCM reg 36(1)(a)(ii). 
trademarks or copyrights. ${ }^{106}$ Where a contractor is the rightholder of an innovative product, design or manufacturing process for which there is no equivalent, an organ of state may have no option but to contract with the rightholder. Failure to do so may prevent the organ of state from having access to the latest technology. ${ }^{107}$ Trepte $^{108}$ correctly cautions, however, that in order to resort to single source procurement for reasons of intellectual property rights,

it will be necessary to demonstrate that there are, in fact, no alternatives. Simply to prefer one type of process which is subject to exclusive rights (which happens to be national) over an alternative process which is itself the subject of exclusive rights may not be sufficient to trigger the derogation. Similarly, holders of exclusive rights may also licence others to manufacture patented products or to use their technical knowledge or manufacturing process. This will happen particularly in cases where undertakings get together to form joint ventures or where subcontractors need to use the proprietary rights held by the contractors in order to fulfil their contractual obligations. The existence of licensees may well give rise to the availability of the protected product from several sources, a situation which would militate against the use of this derogation.

One of the recent 'questionable contracts' in the City of Cape Town concerns the award of a 'jewellery city contract'. ${ }^{109}$ It is reported that the contract was awarded to a consultant (contractor) without the calling of tenders. The City claims that the contract was awarded to the successful contractor because it was an expert in the field and also, that the contract was of an urgent nature. $A$ contractor who later learned of the award of the contract, however, claims that the contract should have been awarded to it since it 'initiated' the jewellery project. The contractor accordingly intends to sue for intellectual theft. ${ }^{110}$ The

106 On the law of patents, trade marks and copyright generally, see Havenga et al Principles of Commercial Law ch 18. See also the Trade Marks Act 194 of 1993; the Copyright Act 98 of 1978; and the Patents Act 57 of 1978.

107 Trepte Public Procurement in the EC 123.

108 Trepte Public Procurement in the EC 124.

109 Anon 2005 http://www.DailyTenders.co.za 14 Apr; Anon 2005 http://www.iafrica.com 14 Apr; Powell Cape Times 8 December 20051.

110 Ibid. 
jewellery city contract is currently (30 April 2006) among a number of contracts concluded by the City of Cape Town that are the subject of investigations. ${ }^{111}$

\subsubsection{Necessary additional and unforeseen work $^{112}$}

It may be necessary to suspend the use of competition, and therefore tender procedures, where necessary additional and unforeseen work needs to be carried out under an existing contract and the work cannot be technically separated from the main contract without great inconvenience. ${ }^{113}$ The same applies in the case of the repetition of similar work, that is, work originally awarded by way of competitive (tender) procedures that needs to conform to a basic project. ${ }^{114}$ In the latter instance, however, it is important for legislation to stipulate a time period within which contracts may be awarded to the same contractor. It is suggested that legislation should stipulate that a contract may only be awarded to a particular contractor on the ground of repetition of similar work during the three years following the award of the original contract to such contractor. ${ }^{115}$

111 Powell Cape Times 11 April 2006 1, 3 and 10; Powell Cape Times 13 April 2006 3. For the author's view on the 'jewellery city contract', see par 4.3.4 below.

112 Can also loosely be referred to as 'the extension of contracts'.

113 See US FAR 6.302-1. See also Powell Cape Times 12 April 20061 who reports on a R5 million contract which was extended by R3 million by the City of Cape Town without the use of tender procedures. It is reported that the non-use of tender procedures was reasoned (by the City of Cape Town) to be in the 'public interest'. The non-use of tender procedures is, however, likely to be the subject of an investigation.

114 See Arrowsmith Procurement and Judicial Review 64; Bright Public Procurement Handbook 38; Trepte Public Procurement in the EC 128. See also a 22 of UNCITRAL http://www.uncitral.org 28 Oct which provides that a procuring entity may engage in 'single-source procurement' in a number of situations, including where procurement from a particular supplier is required for purposes of standardisation or compatibility.

115 See Case C-385/02 Commission of the European Communities v Italian Republic OJ C 323 of 21.12.2002 (ECJ held that since original contracts awarded in 1982 and 1988, agency could not in 1997 award contract to same contractor on the ground of repetition of similar work). See also Brown 2005 PPLR. 


\subsubsection{Amendments to existing contracts}

The use of single source procurement may be justified in the case of amendments being made to an existing contract. It is suggested, however, that in such a case, much will depend on the nature and scope of amendments made. If amendments give rise to the creation of an entirely new contract or a contract that is substantially different from the one initially advertised and concluded, it may well, from a fairness and competitiveness point of view, be necessary for an organ of state to make use of public tender procedures. This will, however, depend on the concrete circumstances of each and every case. $^{116}$

\subsubsection{A need for proper safeguards}

In all the above instances (intellectual property rights, necessary additional and unforeseen work, and amendments to existing contracts), making use of competitive procedures, and this includes tender procedures, is likely to lead to greater costs incurred. The principle of cost-effectiveness and efficiency may therefore warrant the non-use of competition, that is, a tender call, or the use of single source procurement. It is important, however, for proper safeguards to be in place where use is made of single source procurement. A claim, for example, that there is only one potential provider for the particular goods or services should be fully justified and supported by detailed and compelling evidence. $^{117}$ Organs of state should not, for example, be allowed to award custom-made contracts, that is, contracts that are "tailored to the strengths of a particular supplier". ${ }^{118}$ Such contracts clearly defeat compliance with, in

116 For a detailed examination of the rules that apply to the amendment of government procurement contracts, see Bolton Government Procurement ch 7, par 5.2. See also Bolton 2006 Stell LR.

117 For a detailed overview of the manner in which organs of state could be required to justify the use of single source procurement, see US FAR 6.303 which generally deals with justifications for procurement other than by way of full and open competition.

118 Fontanot 2005 http://www.accountancysa.org.za/ 28 Oct. 
particular, the principles of fairness and competitiveness in section 217(1) of the Constitution.

The onus is further on organs of state to prove that no reasonable alternative or substitute exists for the goods or services in question. ${ }^{119}$ In a United States case, for example, the Treasury Department (US Mint) held the United States marketing rights to the Olympic Commemorative Coin program. Maison Lazard, however, held the international marketing rights. Maison Lazard used coin cases manufactured by Unique Packaging Sales Corporation, which would be sold in the United States. The Treasury Department, deciding it had a need for many coin cases, contracted with Unique Packaging Sales Corporation on a sole source basis for thousands of cases. Another supplier, Design Pak Incorporated, then protested to the General Accounting Office and filed suit in the United States District Court arguing that the award was improper because other producers could meet all the requirements of the Treasury. The General Accounting Office ruled that the contracting officer's determination that only one offeror's product met the government's needs and alternate products could not be delivered in sufficient time was not an adequate justification for a sole source award. The General Accounting Office stated:

[w]e believe that Treasury confused its minimum need for a presentation case that satisfied its performance requirements with the characteristics... of [Unique Packaging Sales Corporation's] particular case which happened to satisfy those requirements.

At least one other supplier had indicated that it could produce 190,000 coin cases per week. ${ }^{120}$ The General Accounting Office ruled that -

119 See cl 4.5 in the Green Paper on Public Sector Procurement Reform where it is proposed that insofar as the appointment of consultants is concerned, "[t]he appointment of sole service providers should be permitted, subject to adequate justification on the grounds of the scarcity of their skills and experience, value for money being obtained, and the likelihood that the outcome of the assignment would be compromised without such a selection". See also Case C-57/94 Commission of the European Communities v Italian Republic [1995] ECR I-01249 (ECJ held that derogations from prescribed procurement processes are exceptional; awarding authorities face a heavy burden to prove the existence of the relevant circumstances warranting derogation).

120 See also Sabreliner Corp Comp Gen Dec B-288030 et al. 2001 CPD 170 (held that agency's proposed award of sole source contract for engineering and overhaul services 
in these circumstances, we believe that Treasury was required to solicit for alternative approaches that might have satisfied its need for an appropriate [coin] case.... Had this been done, the forces of competition might well have encouraged offerors to use their ingenuity and inventiveness in proposing designs and approaches that could also have satisfied Treasury's actual needs....A decision to make a sole-source award is unreasonable if the agency had adequate time to assess its needs and conduct a more competitive procurement...but failed to do so or otherwise took improper action which created the urgency. ${ }^{121}$

The District Court in this case had issued a temporary restraining order blocking performance, pending receipt of the General Accounting Office's decision. After receiving the decision that upheld the protest, that court however dismissed the action on the ground that it lacked jurisdiction to permanently enjoin the contract actions in post-award bid protests. ${ }^{122}$

for helicopter engines on the basis that only one firm was capable of meeting agency's needs not reasonable where agency's documentation, including submissions prepared in response to the protest, and agency testimony at the hearing were inconsistent and inaccurate).

121 Design Pak Inc B-212, 579, 83-2 CPD 336. See also National Aerospace Group Inc B282, 843, 99-2 CPD 43 (held that agency's justification for sole-source procurement inadequate where documentation does not reasonably show that only this exact product will satisfy agency's needs, and does not show that agency's need for the item is of unusual and compelling urgency that was not created by a lack of advance planning). See, however, Essex Electro Engineers Inc B-250, 437, 93-1 CPD 74 (held that agency's decision to limit urgent non-competitive procurement for diesel engine electric power plants to one source was reasonable and not the result of a lack of advance procurement planning where the power plants were urgently needed to correct an unacceptable level of military readiness in the Patriot Missile System; the power plants were readily available from only one source, and any delay on the part of the agency in initiating the acquisition was the result of reasonable deliberation that resulted in limiting the acquisition to the minimum number of power plants necessary to satisfy the urgent requirements). See also Greenbier Industries Inc B-241304, 91-1 CPD 336 (protest against sole-source award of contract for chemical protective suits denied where contracting agency reasonably determined that only one company was capable of expeditiously providing a suit amenable to use in "Operation Desert Shield").

122 Design Pak Inc v Regan DC DC No 83-2628 9/16/83. See, however, B-225400 December 121986 (since sole-source award improperly justified, protestor entitled to recover costs of pursuing protest). See also American Sterilizer Company 64 Comp Gen 868 (1985). In Comp Gen B-223914 (Oct 1986) (unpublished), the protestor was able to recover the costs of pursuing the protest, including attorney fees, where the agency failed to show that its urgent circumstances prevented it from requesting offers from as many potential sources as was practicable prior to making a sole source award on the basis of urgency. 
In the case of the recent City of Cape Town 'jewellery city contract', ${ }^{123}$ the onus will be on the City of Cape Town to prove that the non-use of tender procedures was justified. The City will have to prove by way of detailed and compelling evidence that (as allegedly claimed) the successful contractor was the only expert in the field, and that the contract was of an urgent nature.

\section{Conclusion}

By nature, a public call for tenders has the potential to ensure compliance with all the principles in section 217(1) of the Constitution. It is important, therefore, for there to be clear guidelines for the non-use of tendering as a procurement method. At present (30 April 2006), legislation at all three levels of government prescribes that, subject to certain exceptions, contracts with a high value (above R200 000) are subject to public tender procedures. Most relevant, is that organs of state need not call for tenders in the case of 'emergencies', when a call for tenders is 'impractical', and/or in the case of a 'sole supplier'. Little guidance is, however, provided on what would amount to 'emergencies', when tendering may be 'impractical', and when use may be made of 'sole suppliers'.

The aim of this article has been to make recommendations on how the relevant legislative provisions should be interpreted in order to align them with the principles in section 217(1) of the Constitution. With reference to a number of international instruments, it was suggested that tendering may be 'impractical' when tender specifications are not known to an organ of state. A public call for tenders requires an organ of state to draw up detailed specifications so that interested parties are able to submit responsive tenders. If an organ of state is unable to specify its needs, the use of tendering is clearly impractical. Tendering may also be 'impractical' when there has been a call for tenders but no tenders were received or 'inappropriate' or 'unacceptable' tenders were received. Tenders will be 'inappropriate' or 'unacceptable' if, for example, the 
prices offered were too high; unacceptable technical solutions were offered; none of the tenders received complied with the specifications and conditions of the tender call; and/or there has been collusion in the submission of tenders. Reasons of national security could also justify the non-use of tender procedures. When an organ of state is in need of professional advice or services, a public call for tenders may similarly be 'impractical'. An organ of state may not necessarily know the nature, extent or scope of the services to be performed, for example, in the case of research and development, policy formulation, human resource development, community-based developments and the like.

Examples of emergencies may include, inter alia, the likelihood of human injury or death; the likelihood of damage to property, or suffering and death of livestock and animals; the likelihood of serious damage occurring to the natural environment; and/or the possibility that the security of the state could be compromised. Organs of state should not, however, be allowed to make use of emergency procurement procedures if the circumstances giving rise to the emergency were in fact foreseeable, or are the result of negligence, for example, inadequate planning. The fact that an organ of state is unable to use public tender procedures also does not mean that it can do away with competition all together - it may still be able to make use of some other competition, for example, a call for quotations.

The use of tendering may clearly be inappropriate where there is only one provider for the particular goods or services, for example, in the case of intellectual property rights such as patents, trademarks or copyrights. Single source procurement may also be appropriate where necessary additional and unforeseen work needs to be carried out under an existing contract, and the work cannot be technically separated from the main contract without great inconvenience. Single source procurement may further be warranted in the case of amendments made to existing contracts. In such instances, however, much will depend on the scope of amendments made. Generally, amendments should not give rise to an entirely new contract or a contract that is substantially different from the contract initially advertised. 
The use of single source procurement by organs of state may thus be warranted in certain circumstances. Of all the procurement methods, however, single source procurement has the potential to defeat compliance with all the principles in the Constitution. It is important, therefore, for proper safeguards to be in place. A claim that there is only one provider for the particular goods or services should be fully justified and supported by compelling evidence. The onus is also on an organ of state to prove that no reasonable alternative or substitute exists for the goods or services in question. 


\section{Bibliography}

Anon $2004 \mathrm{~J}$ of Public Procurement

Anonymous "Emergency procurement flexibilities: a framework for responsive contracting and guidelines for using simplified acquisition procedures" 2004 (4) Journal of Public Procurement 117-132

Arrowsmith 1998 ICLQ

Arrowsmith $\mathrm{S}$ "Towards a multilateral agreement on transparency in government procurement" 1998 (47) International and Comparative Law Quarterly 793-816

Arrowsmith Procurement and Judicial Review Arrowsmith S Government Procurement and Judicial Review (Carswell Toronto 1988)

Arrowsmith Public and Utilities Procurement

Arrowsmith S The Law of Public and Utilities Procurement $2^{\text {nd }}$ ed (Sweet \& Maxwell London 2005)

Arrowsmith et al. Regulating Public Procurement Arrowsmith SL, Linarelli J and Wallace D Jr Regulating Public Procurement: National and International Perspectives (Kluwer Law International London 2000)

Bolton 2006 Stell LR

Bolton $\mathrm{P}$ "Scope for negotiating and/or varying the terms of government contracts awarded by way of a tender process" 2006 (2) Stellenbosch Law Review (forthcoming)

\section{Bolton Government Procurement}

Bolton P The Legal Regulation of Government Procurement in South Africa (unpublished LLD thesis University of the Western Cape 2005) 
Bright Public Procurement Handbook

Bright C Public Procurement Handbook (Wiley Chancery Law London 1994)

Brown 2005 PPLR

Brown A "Grounds for dispensing with competition under Works Directive 93/97: a note on Case C-385/02 European Commission v Italy on Flood Protection Works" 2005 (1) Public Procurement Law Review 5-7

Burton Legal Thesaurus

Burton WC Burton's Legal Thesaurus $3^{\text {rd }}$ ed (McGraw-Hill New York 1998)

Claassen Legal Words and Phrases

Claassen CJ Dictionary of Legal Words and Phrases Vol 2 E-M (Butterworth Durban 1976)

Collins English Dictionary

Collins English Dictionary: Complete and Unabridged $6^{\text {th }}$ ed (HarperCollins Publishers Great Britain 2003)

Evenett and Hoekman Transparency

Evenett SJ and Hoekman BM "Transparency in Government Procurement: What can we Expect from International Trade Agreements?" in Arrowsmith S and Trybus M (eds) Public Procurement: The Continuing Revolution (Kluwer Law International London 2003) 269-282

Goyder EC Competition Law

Goyder DG EC Competition Law $4^{\text {th }}$ ed (Oxford University Press Oxford 2003)

Havenga et al Principles of Commercial Law

Havenga P et al. General Principles of Commercial Law $5^{\text {th }}$ ed (Juta Cape Town 2004) 
Katayama 1968-1969 PCLJ

Katayama RN "Emergency procurement powers" (1968-1969) Public

Contract Law Journal 236-264

Mkhize "No title"

Mkhize ZL (MEC for Finance and Economic Development) paper presented at the Supply Chain Management Conference: Transforming Government Procurement System (Durban South Africa 22-23 November 2004: on file with author)

Penfold and Reyburn Public Procurement Penfold G and Reyburn P "Public Procurement" in Chaskalson et al (eds) Constitutional Law of South Africa $2^{\text {nd }}$ ed (Juta Cape Town 2003) 25-i to 25-36

Powell Cape Times 8 December 20051

Powell A "City project: Dexter to sue for 'theft of idea"' Cape Times 8 December 20051

Powell Cape Times 12 April 20061 Powell A "Another city tender scandal" Cape Times 12 April 20061

Powell Cape Times 13 April 20063

Powell A "Audit on cards as jewellery city figures 'do not tally"' Cape Times 13 April 20063

Powell Cape Times 11 April 2006 1, 3, 10

Powell A "Now tender boss defies city council" Cape Times 11 April 2006 1, 3,10

Schwarts "Katrina's lessons"

Schwarts Jl "Katrina's lessons for ongoing US procurement reform efforts" presented at the Public Procurement: Global Revolution III Conference, 
University of Nottingham United Kingdom 19-20 June 2006 (on file with author)

Trepte Public Procurement in the EC

Trepte P Public Procurement in the EC (CCH Europe 1993)

Turpin Government Procurement and Contracts

Turpin C Government Procurement and Contracts (Longman London 1989)

\section{Register of statutes and legislative instruments}

Constitution of the Republic of South Africa 1996

Copyright Act 98 of 1978

Local Government Laws Amendment Act 51 of 2002

Local Government Transition Act 209 of 1993

Local Government: Municipal Finance Management Act 56 of 2003

Local Government: Municipal Finance Management Act 2003: Municipal Supply

Chain Management Regulations (Government Gazette No 27636 of 30 May 2005)

Local Government: Municipal Systems Act 32 of 2000

Local Government: Municipal Systems Amendment Act 44 of 2003

National Treasury: Regulations for Departments, Trading Entities,

Constitutional Institutions and Public Entities: Issued in terms of the Public

Finance Management Act 1999 (Government Gazette No 27388 of 15

March 2005)

Patents Act 57 of 1978

Polish Public Procurement Act 29 January 2004

Preferential Procurement Policy Framework Act 5 of 2000

Preferential Procurement Policy Framework Act 5 of 2000: Draft Preferential

Procurement Regulations (Government Gazette No 26863 of 4 October 2004)

Preferential Procurement Regulations (Government Gazette No 22549 of 10 August 2001) 
Public Finance Management Act 1 of 1999

Public Finance Management Amendment Act 29 of 1999

Trade Marks Act 194 of 1993

\section{Register of government publications and official documents}

Directive 2004/17/EC

Directive 2004/17/EC on coordinating the procurement procedures of entities operating in the water, energy, transport and postal services sectors - [2004] Official Journal of the European Union L 134/1

Directive 2004/18/EC

Directive 2004/18/EC on the coordination of procedures for the award of public works contracts, public supply contracts and public service contracts - [2004] Official Journal of the European Union L 134/114

Ministry of Finance and Public Works

Ministry of Finance and Public Works Green Paper on Public Sector Procurement Reform in South Africa GG No 17928 of 14 April 1997

US FAR

United States Federal Acquisition Regulations

\section{Register of cases}

American Sterilizer Company 64 Comp Gen 868 (1985)

B-225400 December 121986

Case C-385/02 Commission of the European Communities v Italian Republic

OJ C 323 of 21.12.2002

Case C-57/94 Commission of the European Communities v Italian Republic [1995] ECR I-01249

Comp Gen B-223914 (Oct 1986) (unpublished) 
Council of Civil Service Unions and others v Minister for the Civil Service [1984] 3 All ER $935(\mathrm{HL})$

Design Pak Inc B-212, 579, 83-2 CPD 336

Design Pak Inc v Regan DC DC No 83-2628, 9/16/83

Essex Electro Engineers Inc B-250, 437, 93-1 CPD 74

Greenbier Industries Inc B-241304, 91-1 CPD 336

National Aerospace Group Inc B-282, 843, 99-2 CPD 43

Ngoasheng v Ekurhuleni Metropolitan Municipality 2004 [JOL] 12953 (T)

Sabreliner Corp Comp Gen Dec B-288030 et al 2001 CPD 170

Scaccia v Borough of Old Forge $373 \mathrm{~Pa}$ 161, 163; 94 A.2d 563, 564 Pa (1953)

\section{Register of Internet sources}

Amos 2005 http://www.egovmonitor.com/ 12 May

Amos J 2005 Freedom of information and procurement [Found on internet] http://www.egovmonitor.com/node/180 [Date of use 12 May 2005)

Anon 2005 http://www.iafrica.com 14 Apr

Anonymous 2005 City defends Cape jewellery project 7 December 2005

[Found on internet] http://www.iafrica.com [Date of use 14 Apr 2006]

Anon 2005 http://www.DailyTenders.co.za 14 Apr

Anonymous 2005 Tender process in R6m Cape deal probed 6 December 2005 [Found on internet] www.DailyTenders.co.za [Date of use $14 \mathrm{Apr}$ 2006]

City of Cape Town http://www.capetown.gov.za 28 Oct

City of Cape Town Procurement Policy Initiative (September 2003) [Found on internet] http://www.capetown.gov.za/procurement/pdf/Policy-

Final\%20ProcurementPolicy.pdf [Date of use 28 Oct 2005]

City of Cape Town http://www.capetown.gov.za/ 4 Apr

City of Cape Town Supply Chain Management Policy (September 2005) 
[Found on internet] http://www.capetown.gov.za/policies/default.asp [Date of use 14 Apr 2006]

COED http://www.askoxford.com 25 Jan

Compact Oxford English Dictionary [Found on internet] www.askoxford.com [Date of use 25 Jan 2005]

Fontanot 2005 http://www.accountancysa.org.za/ 28 Oct

Fontanot P 2005 Tender crimes [Found on internet]

http://www.accountancysa.org.za/Archives/2005mar/features/01 crimes.ht $\underline{\mathrm{m}}$ [Date of use 28 Oct 2005]

Madsen et al. 2002 http://mayerbrown.com/ 26 Jul

Madsen MG, Dowd DF and Farley MJ 2002 Combating terrorism: contracting approaches \& lessons learned Briefing Papers [Found on internet] http://mayerbrown.com/publications/article. $a s p ? i d=173 \&$ nid=6 [Date of use 26 July 2006]

National Treasury http://www.treasury.go.zal $14 \mathrm{Apr}$

National Treasury [no date] Overview of the Policy Strategy to Guide Uniformity in Procurement Reform Processes in Government: Promulgation of a Framework for Supply Chain Management (click "Supply Chain Management") [Found on internet] http://www.treasury.go.za/showpfma.htm [Date of use 14 Apr 2006]

National Treasury 2005 http://www.treasury.gov.za/ 14 Apr

National Treasury 2005 Supply Chain Management Office, Practice Note Number SCM 2 of 2005 "Threshold Values for the Procurement of Goods and Services by means of Petty Cash, Verbal/Written Price Quotations and Competitive Bids" (click: "Treasury Practice Notes", "Supply Chain Management Practice Notes") [Found on internet] http://www.treasury.gov.za/showpfma.htm [Date of use 14 Apr 2006] 
OED http://www.oed.com/ 28 Oct

Oxford English Dictionary [Found on internet] http://www.oed.com/ [Date of use 28 Oct 2005]

Pool and Welch 2005 http://summitinsight.com/ $25 \mathrm{Jul}$

Pool C and Welch B 2005 Responding to Katrina: contracting in an emergency - version 2.0 [Found on internet] http://summitinsight.com/femakatrina.pdf [Date of use 25 Jul 2006]

UNCITRAL http://www.uncitral.org 28 Oct

United Nations Commission on International Trade Law Model Law on Procurement of Goods, Construction and Services 1994 [Found on internet] http://www.uncitral.org/english/texts/procurem/ml-procure.htm [Date of use Oct 2005]

WTO GPA http://www.wto.org 28 Oct World Trade Organisation Government Procurement Agreement [Found on internet] http://www.wto.org [Date of use 28 Oct 2005] 